\title{
EDUCATIONAL NEEDS OF TEACHER FOR INTRODUCTION AND APPLICATION OF INNOVATIVE MODELS IN EDUCATIONAL WORK TO IMPROVE TEACHING
}

\author{
Dr. Biljana Novković Cvetković, Pedagogical Faculty in Vranje, University of Niš, Serbia \\ E-mail: biljananovkovic74@gmail.com \\ Dr. Dragana Stanojević, Pedagogical Faculty in Vranje, University of Niš, Serbia \\ E-mail: draganastanojevic_vr@yahoo.com
}

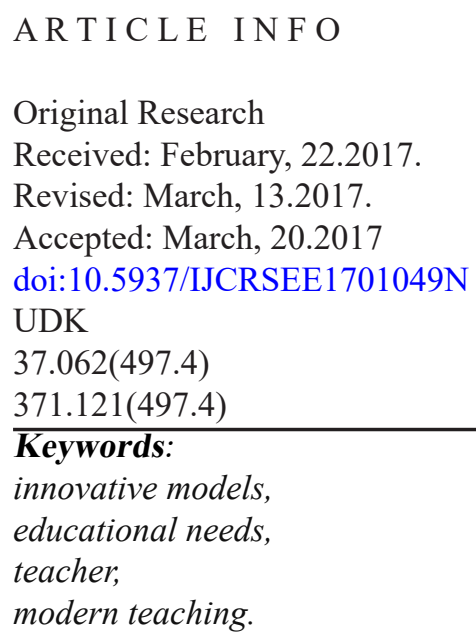

\begin{abstract}
A B S T R A C T
The needs and interests of teachers for the imple-mentation of innovative models in teaching are the key factor that determines raising quality of teaching at the school. In this context, it should be borne in mind that the educational needs of teachers are closely linked to the necessity of lifelong learning, because nowadays the teachers work skills are not enough that they adopted during schooling twenty years ago or more. The paper analyzes the educa-tional needs of teachers in exploring and imple-menting innovative work models of teaching. The greatest interest of teachers is for introduc-tion and implementing individualized teaching.
\end{abstract}

\section{INTRODUCTION}

Although the pedagogical, andragogical and psychological literature devoted many research papers and discussion of educational needs of people in different ages, professions and position in the work process, still cannot be concluded that the achieved responses were fully satisfying. It is a generally accepted standpoint that the needs are in the range from biological to cultural and educational.

In the broadest sense, human needs are defined as dynamic forces that drive human activities and influence his behavior. It is also a generally accepted standpoint that the human needs should and must be studied from various aspects. At multidisciplinary explanation of needs also Maslov (Maslow, 1982) pointed out with his theory of self-actualization and explanations that the needs are hier-

Corresponding Author

Dr. Biljana Novković Cvetković, Pedagogical Faculty in Vranje, University of Niš, Serbia

E-mail: biljananovkovic74@gmail.com

This work is licensed under a Creative Commons Attribution - NonCommercial - NoDerivs 4.0. The article is published with Open Access at www.ijcrsee.com archically related because lower level needs must be satisfied before it activates needs of higher levels. It is also known, that man as a social being, must satisfy the educational needs that are only one relevant part of its total needs throughout his life and work. Hence the talk of lifelong learning as a process that educational needs are satisfied throughout the work and life of man.

Furthermore, it is important to know that the needs are directly related to the desires and endeavors of the individual, not only to supplement the lack of something (homeostasis), but also to contribute to his own development, which brings him satisfaction (selfactualization). This is particularly important for an explanation and identification of training needs of employees in education, including the teachers who work in the immediate teaching practice. In this regard, it should be noted that despite numerous explanations, the nature of human needs in general, and especially the educational needs of employees, there is a dilemma as to whether educational needs or the need for general or specific education, is part of every educational activity, i.e. whether they have the character of employee motivation or they lack motivational force.

It is also a generally accepted under- 
standing by the majority of authors who deal with the problems of educational needs, and regardless of the different views on the structure of educational needs as well as differences in their definition, that they are the basis of every educational activity and that they are an inevitable aspect of any research in education.

Educational needs are the difference between what is and what is necessary or desirable to be between the current, possessed, and reached, desired, anticipated, or demanding standardized state on the other hand (Despotović, 2000). Educational needs are directly related to the individual's wishes and can be a strong driving force in innovation and modernization of educational work in general, and particularly in the modernization of the direct teaching of each teacher.

The needs are the internal initiator of human activity. It is hard to consider something as a need when an individual doesn't experience it as such. If teachers have developed positive attitudes towards innovation, if they perceive innovation as the need for modernization of educational work, then innovations will increasingly enter into the practice of our schools. If teachers aren't motivated enough, innovation, regardless of its internal capabilities, there is no chance for success (Vilotijević, M., Vilotijević, N., 2008).

\subsection{Introducitng innovations in the teaching}

Many educators are engaged in innovation: Mc Clelland D. (1961), Rogers, E., (1962), Schön, D. (1967), Vlahović, B. (1996), Okoń, W. (1978), Prucha, J. (1983), Vlahović, B. (1996), Đorđević, J. (1996), Vilotijević, M., Mandić, M., 2015.

Under the influence of a very rapid progress of science and technology innovations are coming into teaching. But, school as a very conservative institution, takes a long time for scientific and technological break-throughs to be introduced into teaching. Innovations should enable, better use of the teacher's work and technical resources, increasing economic efficiency and increasing performance in teaching and in educational work, increasing productivity. Innovation is the requirement that the school is not lagging behind the social and technological changes in the reality that every day intensive change (Vilotijević, M., Mandić, M., 2015).

Substantial cause for the slow penetration of innovation in the teaching process is the conservatism of a large number of teachers who feel safer when they apply traditional methods, proven methods and resources, rather than innovation, whose results they suspect (Vilotijević, M., Mandić, M., 2015). Conservatism and traditionalism of teacher's area major obstacle to the entry of information technology in teaching and learning. Reactions of teachers to introduction of new technologies and innovation in school ranges between two extremes - from complete enthusiasm to the decisive rejection. Most of them are moderate in their attitudes towards multimedia. They consider multimedia welcome and want to incorporate it into their lessons, but they are still reserved to the technology itself, its purpose in teaching and learning and support to teachers and students who use it. This means that they should have quite a specific theoretical knowledge and practical skills for programming, introduction to teaching practice, monitoring and evaluation of innovative models of work. This ability implies not only knowledge of the content, i.e. expert knowledge in the field where innovation is done by applying innovative models of work, but also quite certain methodical knowledge (Banđur, 2001).

Potkonjak says that the basic, most important and key factor and carrier innovation in the educational and teaching organized in school is the teacher. Without an innovative teacher, there can be no innovative school"(Potkonjak, 2013).

Classes in quality - innovative school itself should be such, quality and innovative. "To make the learning process, good, interesting, rich, innovative, indispensable wellprepared teachers are highly competent and didactic - methodical culture, the teachers themselves are constantly improving. Teaching has the necessary qualities if respected cognitive and other differences among students and enables everyone to solve tasks in their own way "(Vilotijević, M. 2000).

Stošić says that teachers, students and the school itself have now found themselves in a very different information environment than before. Schools that accept this environment will be much more modern and more successful and will not look like traditional schools where the teacher and the textbook are the only available sources of knowledge. By applying information technology, schools can continually innovate their new knowledge. Innovation is the requirement so that the school does not remain at the traditional level (Stošić, Stošić, 2013). 
Educational innovations are the connective "tissue" of the information society without it's changes it cannot be. Promotion and realization of innovation in the information society in all aspects represents a large number of industry specific factors. But the main factor of these activities is man and his ability and willingness to innovate enriches the educational process. To make educational innovations enter the realization and development of the information society requires a collective competence for innovative activities. (Брындин, Е. Г. 2011)

A teacher's decision to accept or reject the innovation is conditioned by many factors. Mr. Vilotijević says that the teacher is faced with more choices: a) he may adopt it if it is in accordance with his understanding of the essence of the teaching process; $b$ ) he can accept it as a potential asset, but to elaborate and upgrade it in accordance with his vision of teaching, and only than to apply it; c) he can wait with application until he realizes if this innovation is accepted by other teachers; d) he can completely reject it; e) he can partially correct his vision of the teaching problem in accordance with the knowledge and understanding of the innovation and then to apply it practically; f) he can completely dismiss his knowledge and understanding of a certain educational problem and to accept the innovation (Vilotijević, G., 2011).

\subsection{Theoretical orientations about teaching and studying}

For the teaching process and education in general what is very important are theoretical orientations, which should contribute to the increase of the quality in teaching activity to a higher level. Among the most recenttheories of studying are interactive, constructive and humanistic.

Interactive theories are based on Hegel's postulate of the "I" identity, which states that identity and self-confidence cannot be formed without an interaction between the "I" and others. This idea is present in the critical theory of the Frankfurt philosophic group, which insists on a democratic discourse as a way of reaching truths and cognition. On these ideas, criticalcommunicative didactics were developed, in which the student-student and student-teacher interaction is one of the key categories. That is in collision with the educational process, in which the student is the object. What is required is that the teacher-student interaction, although asymmetric, should be a relation of mutual respect even though students are less experienced than teachers. Petersen points out that didactics, especially communicative one, in its basis have to have three important factors: interactive relation to the educational process, the school obligation to act socially, and finally, the attitude towards the existence of the acting subject. Bruner and Vigotski point out in their conceptions of studies that interaction has great importance for personal development of a student. Interaction is the base of cooperative teaching, which was the topic of many of our authors, among whom are I. Ivić, D. Branković, N. Suzić, and others. The basic assumption for the interactive teaching is modeling of working and living situations, scenic reviews, mutual problemsolving. There is no domination of any of the participants in the educational process. Each student is a subject, each one of them actively participates in the studying process, and each one has his or her studying path. The teaching process is democratic, students and teachers work together. Every individual brings his own individuality into the teaching process. They also bring their knowledge, experience, ideas, and a way of activity. Forms of work are individual, in pairs or in groups. What is created is the environment of educational interaction, which is characteristic for its openness, mutual interaction of the participants, breach of arguments, mutual marking and control. Feedback is obligatory.

Famous psychologist Wartofsky (1990) says that a child is not some special person who is developed from some fixed configura-tion of characteristics, dispositions and previously created possibilities. On the other hand, the world is not some eternal and objective network of conditional factors, which are acquired at birth, so that from a passive succumbing ball we could shape it into an externally predetermined structure. The child is a participant in its personal formation, as well as the formation of the world, but that participant whose participation develops in the context of the inevitable social and historical practice.

This Wartofsky's attitude is in a complete accordance with the theories of Z. Piaget and L. Vigotsky, in which they point out that the influence of the environment onto the individual and vice versa. Bytheir nature, these theories are interactive because they point out the interaction between an individual and the environment as a development priority, but between them there are certain differences in relation to the role of particular environmental 
elements in the process of development. Both these theoreticians perceive the development as a series of qualitatively different phases, not as piling of developmental cubes. A child grows and matures through universal developmental phases, characteristic of certain age, but going through the physiological development is not enough. It is necessary for a child to be active in its environment. In constructive conception, especially with Piaget, it is necessary for an individual to possess cognitive imbalance, that is, confrontation between what they already know and new knowledge. As long as an individual can assimilate the surrounding world, the development goes through the same phase. If the existing cognitive structure of an individual is too narrow and cannot accept new information, then it is accommodated or changed and thus moves onto a higher level. This is, by Piaget, the confrontation between the view of an individual in the world and the environmental objects which cannot be embedded into their cognitive schemes, so they are forced to create new ones, and by doing so, assimilation and accommodation are permeated.

From Piaget's theory, a very important pedagogical message can be deduced: student's cognition has to be the result of their activity through which they create their cognitive structures.

The student's activity should not be understood only as their relationship with the physical environment, but also as a thinking activity, since activity goes from the external into the internal, mental plan.

Although Piaget pointed out the importance of social relations for the development of an individual, this is more stressed with Vigotsky, who underlines an important formative function of social interactions, without which there is no development. It is a mechanism in which the biological in an individual becomes cultural. Teacher and student are in an asymmetric interaction since the former has more knowledge and experience than the latter. Vigotsky considers this asymmetry as a developmental factor since it enables the formation of functions which become the student's property. Developmental improvement starts from the zone of real development which a student has already acquired and is moving into the zone of the next level of development which a student has yet to acquire. The pedagogical value of this assumption is extremely important. In the zone of the next level a student cannot acquire certain functions by himself, but he will be able to if helped by a teacher. The zone of the next developmental level is characteristic of the fact that a new structure is started on it, which, with help of a certain teacher, can be completely formed. In that zone, the influence of the teacher has the largest developmental effects, that is, it contributes to the acquisitions of new cognitive structures.

A new dimension in education and studying has been started by the humanistic theory. Its founder, Abraham Maslov (1982), in his work Motivation and Personality incline in his approach to man and studying to internal determination in contrast to the behaviorist Skinner, who pointed out external determination as crucial to both behavior and studying. Considering education more widely than it was traditionally accepted, Maslov points out that it is primarily necessary to nourish humanity in each individual. He does not consider learning primarily as pure acquisition of associations, habits and skills which by its character refer externally to a man. Truly, it is a useful part of a person's studying in the technological society, which helps him study objects and things more easily. A man can practice his habits by using a behavioristic approach, can study a foreign language by using a method of associations, but in that way, he cannot be taught humanity. Apart from that, the world can give someone only what he or she is up to, what he or she is suitable for, and finally, a person can get from the world or give to it only what he or she represents. Maslov reckons that today we can clearly see two explicit approaches to studying. In the first approach, education is considered as transferring of knowledge necessary for the industrial society. Students do not ask themselves why they study and what for. The basic concern of school is efficiency, that is, to make students acquire as many facts as possible with minimal spending of time, money and energy. The function and the main goal of education is, in its nature, human. A pedagogist, in that case, is interested in self-actualization, that is, to help the student grow into a good man as much as possible.

The two mentioned approaches are external and internal. The humanistic approach is characterized by internal education which enables the student to acquire such knowledge and skills which will make him a good person. In that case, the problem of education will not come down to a requirement for acquisition of information with a less or bigger waste of time and money, but how the student will best understand and evaluate that piece of informa- 
tion, so that he could include it into his experience for further usage in various areas of life and work. In that case, knowledge becomes useful, as well as the learning process itself.

\section{MATERIALS AND METHODS}

About innovative teaching models written by many authors, among them Mandić, Р. (1977), Махмутов, М. И., Мирза, И. М. (1977), Vilotijević, M., Vilotijevic, N. (2008), Лазарев В. C. (2008), Suzić, N. (2007) and other.

The subject of our empirical research is to examine the attitudes and opinions of teachers about the impact of innovative working models in teaching in the function of improving the quality of educational work in school.

Accordingly, we set a goal of this research - to determine the educational needs of teachers for exploring and implementing innovative models in teaching and that the views and needs, as well as the dependent variable, bring into a functional relationship with gender, level of education and work experience, as independent variables of research.

It was placed as the starting general hypothesis that teachers express a strong need for exploring and implementing innovative models of teaching in total, and there are no statistically significant differences in the needs of the respondents for exploring and implementing innovative models in teaching based on their gender, level of education and work experience.

In this study was used the descriptive scientific and research method in its pronounced analytical variant (Survey research method). By using this method, data will be collected about the attitudes of teachers towards the implementation of innovative models, which will allow the detection of relevant causal connections and performing the appropriate conclusions about the impact of innovation on the quality of the teaching process.

In statistical analysis of the obtained data were used in the following statistical procedures:

1. $\chi 2$-test we will apply to the processing of data provided in the form of frequencies (i.e. qualitative data). Cumulative trait of the $\chi 2$-test allows combining a greater number of other values in the same test. The significance of the hypothesis that contain more data sets we will calculate to the established pattern.

2 . For testing the significance of differences in independent samples of our research, we will apply rank sum test (WilcohonomTest or Mann-Whitney U-test). Value of rank sum test we will calculate with the established pattern.

Given tasks and associated with hypothesis, will be tested on a representative sample which will consist of 300 teachers of six elementary schools in Vranje. The sample will be stratified - just a random character which will enable him to look like on the basic set from which it was taken. We combined a group of intentional (stratified) samples with unintentional (just-random) samples, by which we ensure that respondents are grouped into subgroups (stratums) and selection of respondents in sample may be made within the stratum, using a sample just-random nature.

\section{RESULTS AND DISCUSSIONS}

In order to investigate the educational needs of teachers for exploring and implementing innovative models of teaching a Likert scale is constructed, with the list of twenty statements. It evaluated the innovative models of teaching according to the degree of interest of teachers. Teachers were instructed to respond as much as they are interested for training in the field of innovative models in teaching, on the scale: "I'm very interested", "I'm interested", "I'm mostly interested", "I'm not interested", "I'm really not interested". In the so constructed scale of attitudes of teachers' answers "I am very interested "were estimated by five points, and the answer "I am very uninterested" with one point.

In this way, by adding the answers for all teachers at all innovative working models of teaching it would be possible to determine the cumulative value (cumulative index) for each innovative model and scale as a whole. And so are determined individual gross scores (individual score) for each teacher, and the whole scale.

Then they calculated the scale value, or the arithmetic mean (M) as the average value assessment of interest in exploring and implementing innovative working models of teaching at all innovative models, as can be seen from the results that are presented in the tables. Analysis of so presented results of descriptive statistics for understanding the educational needs of teachers for exploring and implementing innovative models of teaching shows the largest teachers' interest in learning about the application: individualized teaching $(\mathrm{M}=4.39)$, programmed teaching $(\mathrm{M}=4.17)$, 
problem teaching $(\mathrm{M}=4.05)$ and computerinformative teaching $(\mathrm{M}=4.01)$.

Table 1. Descriptive statistics for understanding the educational needs of teachers for exploring and implementing innovative models in teaching

\begin{tabular}{lcccc}
\hline Innovative models & Mean & Std. Dev. & Skewness & Kurtosis \\
\hline $\begin{array}{l}\text { 1. Individualized } \\
\text { teaching }\end{array}$ & 4.39 & .77 & -1.20 & 1.08 \\
\hline $\begin{array}{l}\text { 2. Programmed } \\
\text { teaching }\end{array}$ & 4.17 & .94 & -1.40 & 2.88 \\
\hline $\begin{array}{l}\text { 3. Problem } \\
\text { teaching }\end{array}$ & 4.05 & .91 & -1.09 & 1.37 \\
\hline $\begin{array}{l}\text { 4. Computer-in- } \\
\text { formative teaching }\end{array}$ & 4.01 & 1.04 & -1.13 & 1.44 \\
\hline 5. Team teaching & 3.96 & 1.11 & -1.38 & 2.25 \\
\hline $\begin{array}{l}\text { 6. Developing } \\
\text { teaching }\end{array}$ & 3.86 & .94 & -.24 & -1.00 \\
\hline $\begin{array}{l}\text { 7. Interactive } \\
\text { teaching }\end{array}$ & 3.78 & 1.18 & -1.34 & 2.20 \\
\hline $\begin{array}{l}\text { 8. Meaningfully- } \\
\text { verbal teaching }\end{array}$ & 3.71 & 1.04 & -.55 & -.23 \\
\hline $\begin{array}{l}\text { 9. Integrative } \\
\text { teaching }\end{array}$ & 3.70 & .97 & -.65 & 1.11 \\
\hline $\begin{array}{l}\text { 10. Heuristic } \\
\text { teaching }\end{array}$ & 3.63 & 1.04 & -.22 & -1.10 \\
\hline $\begin{array}{l}\text { 11. Project } \\
\text { teaching }\end{array}$ & 3.63 & 1.06 & -.54 & .22 \\
\hline $\begin{array}{l}\text { 12. Productive } \\
\text { teaching }\end{array}$ & 3.61 & 1.28 & -.79 & .02 \\
\hline $\begin{array}{l}\text { 13.Playacting } \\
\text { teaching }\end{array}$ & 3.60 & 1.12 & -.64 & -.015 \\
\hline $\begin{array}{l}\text { 14. Personally } \\
\text { directed teaching }\end{array}$ & 3.59 & 1.20 & -.91 & .62 \\
\hline $\begin{array}{l}\text { 15. Exemplary } \\
\text { teaching }\end{array}$ & 3.57 & 1.13 & -.48 & -.18 \\
\hline $\begin{array}{l}\text { 16. Micro teaching } \\
\text { 17. Modular } \\
\text { teaching }\end{array}$ & 3.52 & 1.14 & -.53 & -.02 \\
\hline $\begin{array}{l}\text { 18. Experiential } \\
\text { teaching }\end{array}$ & 3.51 & 1.09 & -.50 & .13 \\
\hline $\begin{array}{l}\text { 19. Outpacing } \\
\text { teaching }\end{array}$ & 3.47 & 1.14 & -.36 & -.55 \\
\hline $\begin{array}{l}\text { 20. Distance } \\
\text { teaching }\end{array}$ & 1.137 & -.31 & -.01 \\
\hline Cumulative index & 3.67 & .36 & & \\
\hline
\end{tabular}

The least interest was manifested to learn and use: personally-directed teaching $(\mathrm{M}=3.59)$, exemplary teaching $(\mathrm{M}=3.57)$, micro teaching $(\mathrm{M}=3.52)$, modular teaching $(\mathrm{M}=3.51)$, experiential teaching $(\mathrm{M}=3.50)$, outpacing teaching $(\mathrm{M}=3.47)$ and learning in distance-distance teaching $(\mathrm{M}=3.37)$.

The results show that the educational needs of teachers, i.e. teachers' interesting in exploring and implementing innovative models of teaching, are not distributed according to the normal distribution, but it is significantly different because it is evident that a much higher percentage of teachers are withmore positive than with the volatile and negative attitudes, according to the obtained Skewness and Kurtosis for each innovative model and for the scale as a whole.

That the teachers are most interested in exploring and implementing individualized teaching, programmed teaching, problem teaching and computer-informative teaching, shows not only the biggest scale values than the percentage of teachers who are interested in their introduction and implementation. Thus, $53.06 \%$ of the teachers pleaded like "very interested" for individualized teaching, $43,87 \%$ for programmed teaching, $33.67 \%$ for a problem-solving, and $38.77 \%$ for computer-informative teaching. On the other hand, only $24.48 \%$ of the teachers pleaded like "very interested" for introduction and application: personally - directed teaching, exemplary teaching $24,48 \%, 22,44 \%$ of micro teaching, $20,40 \%$ modular classes, $21.42 \%$ experiential teaching, $21,42 \%$ outpacing teaching and $17,34 \%$ learning on distance - distance teaching. Obtained results showed that the teachers expressed a great need for exploring and implementing innovative working models in teaching, although there are obvious and significant differences in the intensity of interest in the introduction and implementation of innovative working models in teaching. In fact, there were found significant differences in some innovative models of teaching.

In this way, it confirms the initial hypothesis that respondents express a strong need for the introduction and implementation of innovative models of teaching in total.

\section{CONCLUSIONS}

Needs for innovative interventions in education are distinctive because there is a big discrepancy between the scientific and technical achievements and needs of labor, on one hand, and the quality of the educational process, on the other.

Weaknesses of traditional teaching the dominance of teaching approaches, onesidedness in the application forms, methods, teaching system, media poverty - bring very negative consequences. The teacher is active and the pupils are passive learners; to unequal pupils are placed the same requirements; requires a multitude of facts in which loses rules and laws; encourages the memorizing and disadvantage opinion; required reproduction, and absent application and creativity. The teaching process is uniform and boring, causing apathy among students. Modern achievements of pedagogical science and didactical theory, technical and technological advances, particularly the development of communication- information and media technologies al- 
low traditional organizations of teaching and learning to gradually abandon and to apply organizational solutions, forms, teaching systems, methods and media that will make the learning process more intensive and more efficient. In teaching we must bring innovation.

Innovations have accelerated progress in each activity, as well as teaching at the school. Innovations contribute to greater efficiency of the educational process. The school must be constantly underchanges. Innovation is the requirement that the school does not lag behind other social and technological changes. School, as it was pointed out by Tolstoy must be the laboratory where the continuous experiment, discover and change.

The quality of the teaching process is measured by how much a teacher, while working with students, insistson the practical applicability of the acquired knowledge. This means that he strives to enable students to apply selfsame knowledge in a variety of situations (knowledge transfer). The quality of the applied practical knowledge is far higher than the bookish perfectly mastered content which remained only in the memory of students, and in life was not used. The man is intellectualy, diligently and valuable evolving and forming in practical activities. If working process is valued, it will have a major motivational incentive to teachers who will try to expertly and didactic-methodically perfecting.

Without development and innovative changes there is no raising quality of pedagogical work in school. In order for certain innovations to become an integral part of the teaching process, they must be accepted by the teacher. It is necessary first that teachers know about them and that they have formed positive attitudes. Attitudes, like valuable relation towards innovation, lead to their application in educational reality.

It is known that man as a social being, must satisfy and the educational needs that are relevant to only one part of his total needs throughout his lives and work. Hence the talk of lifelong learning as a process that educational needs are satisfied throughout the work and life of the man.

The results of this study observed as a whole, show that the surveyed teachers do not have the same level of information about the didactical characteristics and values of some innovative models in teaching, because it is evident that there are significant differences in the level of awareness of teachers in this regard. The results showed that teachers are informed with different intensity about some of the innovative models, but that differences were determined only with some innovative models in teaching.

Analysis of the results of descriptive statistics for understanding the educational needs of teachers for introduction and implementation of innovative models in teaching shows that the largest teachers' interest in learning about the application: individualized teaching $(\mathrm{M}=4.39)$, programmed teaching $(\mathrm{M}=4.17)$, problem teaching $(\mathrm{M}=4.05)$ and computerinformative teaching $(\mathrm{M}=4.01)$.

\section{ACKNOWLEDGEMENTS}

We are very grateful to teachers of the primary schools in Vranje, who had supported us in gathering the field data for the study.

\section{Conflict of interests}

Authors declare no conflict of interest.

\section{REFERENCES}

Banđur, V. (2001). Pedagogical and methodological foundation of methodical of class teaching. Belgrade: Faculty of Teacher Education.

Despotović, M. (2000). The game needs - adult education variation. Belgrade: The Institute of Pedagogy

Đorđević, J. (1996). Innovations in teaching. Beograd: Prosveta.

Mandić, P. (1977). Innovations in teaching. Sarajevo: Svjetlost.

Maslow, A. H. (1982). Motivation and personality. Beograd: Nolit.

Mc Clelland, D. (1961). The Achieving SocietThe Achieving Society. New York: Von Nostrand Reinhold co.

Okoń, W. (1978). Współczesne innowacje w kształceniu i wychowaniu [Contemporary innovations in education and upbringing]. Nauczyciel $i$ Wychowanie 3

Potkonjak, N. (2013). School can be innovative only if it has innovative teachers, educational innovation in the information society. Belgrade: SAO, p.75-83.

Prucha, J. (1983). Perpektiwy vzdelany. Praha: SPN.

Rogers, E. (1962). Diffusion of Instruction, New York: The Free Press.

Schön, D. (1967). Technology and change: the new Heraclitus Seymour Lawrence Books. Delacorte Press: Delta book.

Stosic, L., \& Stosic, I. (2013). Diffusion of innovation in modern school. International Journal of Cognitive Research In Science, Engineering And Education (IJCRSEE), 1(1), 5-13. http://www. ijcrsee.com/index.php/ijcrsee/article/view/7/56

Suzić, N. (2007). Hrestomatija - innovation and application of e-classrooms. Banjaluka: HVS

Vilotijević, G. (2011). Web portals in teaching, Educational Technology, 3, Belgrade.

Vilotijević, M. \& Mandić, D. (2015). Management of 
(IJCRSEE) International Journal of Cognitive Research in Science, Engineering and Education Vol. 5, No.1, 2017.

developmental changes in educational institutions. Belgrade: Faculty of Teacher Education.

Vilotijević, M. (2000). The quality of education and schools - the key to the XXI century: Pedagogy, 38(2), 107-142.

Vilotijević, M., \& Vilotijevic, N. (2008). Innovations in teaching. Vranje: Faculty of Teacher Education.

Vlahović, B. (1996). Innovation Management and attachments. Belgrade: Faculty of Teacher Education.

Wartofsky, L. (1990). The Child's Construction of the World and the World's Construction of the Child. New York: Rogoff, B., Apprenticeship inThinking, Oxford University Press.

Брындин, Е. Г. (2011). Коллективная компетентность инновационной деятельности [Collective competence of innovation activity] Межд. науч. жур. «Репутаииология 5, 85-88. http:// elibrary.ru/item.asp?id $=17846398$

Лазарев В. С. (2008). Управление инновачиями в школе [Management of Innovations in School]. М.: Центр педагогического образования

Махмутов, М. И., Мирза, И. М. (1977). Организация проблемного обучения в школе: кн. для учителей [Organization of problematic schooling: For teachers] Просвещение. 